\title{
The Natural Radioactivity Survey of Landslides in Jawa Island.
}

\section{SEIJI TOCHIKI*}

In this report we describe the result of investigation of landslides in Jawa from 25 July to 6 September 1978, which was carried out by professor S. Yamaguchi as representative, Saburo Nakamura, Shigeru Aoki, Yuji Takata and Nobuyuki Takahama.

The author has considered that it is desirable to use simultaneously natural radioactivity survey and electrical surveying method in order to do the drainage works more effectively. So we investigated the natural radioactivity survey as much as possible by the instrument (scintillation surveymeter type TCS $121 \mathrm{C}$ ) in the main landslide areas and the Sabo areas during our investigation tour.

The results of investigation which were obtained in the way described above are shown as follows.

(1) Cipatat along the national road No. 1, west to Bandung, Bd. $22 \mathrm{~km}-\mathrm{Bd} .24 .4 \mathrm{~km}, \quad(0.40-$ $1.00 \times 10^{-2} \mathrm{mr} / \mathrm{h}$, av. $0.64 \times 10^{-2} \mathrm{mr} / \mathrm{h}$ ) (cf. Fig. 6)

(2) Sidaradja, Bd. $60.5-$ Bd. $61.4 \mathrm{~km},\left(0.70-1.00 \times 10^{-2} \mathrm{mr} / \mathrm{h}\right.$, average $\left.0.79 \times 10^{-2} \mathrm{mr} / \mathrm{h}\right)$ (cf. Fig. 7)

(3) Warunpeti, Bd. $68.5-68.8 \mathrm{~km}, \quad\left(0.65-0.95 \times 10^{-2} \mathrm{mr} / \mathrm{h}\right.$, average $\left.0.79 \times 10^{-2} \mathrm{mr} / \mathrm{h}\right)($ Fig. 8$)$

(4) Warungkiara, Bd. $126-\mathrm{Bd} .126 .25 \mathrm{~km},\left(0.20-0.50 \times 10^{-2} \mathrm{mr} / \mathrm{h}\right.$, average $\left.0.40 \times 10^{-2} \mathrm{mr} / \mathrm{h}\right)$ (cf. Fig. 9)

(5) Pasawahan, south to Pelabuhanratu, Bd. $158-$ Bd. $159 \mathrm{~km},\left(0.30-0.60 \times 10^{-2} \mathrm{mr} / \mathrm{h}\right.$, average $0.46 \times 10^{-2} \mathrm{mr} / \mathrm{h}$ ) (cf. Fig. 10)

(6) Pasawahan, Bd. $164.85-$ Bd. $165 \mathrm{~km},\left(0.90-1.30 \times 10^{-2} \mathrm{mr} / \mathrm{h}\right.$, average $\left.1.08 \times 10^{-2} \mathrm{mr} / \mathrm{h}\right)(\mathrm{cf}$. Fig. 11)

(7) Pasikusalam, south to Sukabumi, Bd. $118 \mathrm{~km}, \quad\left(0.50-0.55 \times 10^{-2} \mathrm{mr} / \mathrm{h}\right.$, average $0.51 \times 10^{-2}$ $\mathrm{mr} / \mathrm{h}$ ) (cf. Fig. 12)

(8) Rantjaorai, Bd. $117\left(0.40-0.60 \times 10^{-2} \mathrm{mr} / \mathrm{h}\right.$, average $\left.0.48 \times 10^{-2} \mathrm{mr} / \mathrm{h}\right) \quad$ (cf. Fig. 12)

(9) Tikawung Warungpeuteui, Bd. $115\left(0.35-0.60 \times 10^{-2} \mathrm{mr} / \mathrm{h}\right.$, average $\left.0.46 \times 10^{-2} \mathrm{mr} / \mathrm{h}\right)$ (cf. F!g. 12)

(10) Tjisogan, Bd. $52 \mathrm{~km},\left(0.50 \times 10^{-2} \mathrm{mr} / \mathrm{h}\right)$

(11) South to Cianjur, Bd. $125 \mathrm{~km},\left(0.50 \times 10^{-2} \mathrm{mr} / \mathrm{h}\right)$

(12) South to Cianjur, Bd. $121.5 \mathrm{~km},\left(0.30 \times 10^{-2} \mathrm{mr} / \mathrm{h}\right)$

(13) South to Cianjur, Bd. $116.5 \mathrm{~km},\left(0.30 \times 10^{-2} \mathrm{mr} / \mathrm{h}\right)$

(14) South to Bandung, Bd. $50 \mathrm{~km},\left(0.35 \times 10^{-2} \mathrm{mr} / \mathrm{h}\right)$

(15) Pintmurabaru, Bd. $46 \mathrm{~km}, \quad\left(0.25 \times 10^{-2} \mathrm{mr} / \mathrm{h}\right)$

(16) Pangalengan, Bd. $38.1 \mathrm{~km},\left(0.65 \times 10^{-2} \mathrm{mr} / \mathrm{h}\right)$

(17) Bandung, (0.75 $\left.\times 10^{-2} \mathrm{mr} / \mathrm{h}\right)$

(18) The top of G. Tangkubanparahu, $1830 \mathrm{~m}$ above sea level, $\left(0.75 \times 10^{-2} \mathrm{mr} / \mathrm{h}\right)$

* Professor of Sabo-Engineering Hiroshima University Faculty of Integrated Arts and Sciences 
地すべり Vol. 17, No.1 (1980)

(19) A hot spring, south to G. Tangkubanparahu, $1500 \mathrm{~m}$ above sea level $\left(1.35 \times 10^{-2} \mathrm{mr} / \mathrm{h}\right)$

(20) Maribaya, north to Bandung, $\left(0.95 \times 10^{-2} \mathrm{mr} / \mathrm{h}\right)$

(21) South to Maribaya, $\left(0.65 \times 10^{-2} \mathrm{mr} / \mathrm{h}\right)$

(22) Surabaya, $\left(0.45 \times 10^{-2} \mathrm{mr} / \mathrm{h}\right)$

(23) Tokol Sabo-dam, $\left(0.23 \times 10^{-2} \mathrm{mr} / \mathrm{h}\right)$

(24) Selorejo dam, $\left(0.20 \times 10^{-2} \mathrm{mr} / \mathrm{h}\right)$

(25) Malang, $\left(0.45 \times 10^{-2} \mathrm{mr} / \mathrm{h}\right)$

(26) Karangkates dam, $\left(0.15 \times 10^{-2} \mathrm{mr} / \mathrm{h}\right)$

(27) Lahor dam, $\left(0.32 \times 10^{-2} \mathrm{mr} / \mathrm{h}\right)$

(28) Wlingi dam, $\left(0.20 \times 10^{-2} \mathrm{mr} / \mathrm{h}\right)$

(29) K. Putih sand pocket, $\left(0.25 \times 10^{-2} \mathrm{mr} / \mathrm{h}\right)$

(30) Tjandipenataran, $\left(0.25 \times 10^{-2} \mathrm{mr} / \mathrm{h}\right)$

(31) Jatilengger sand pocket, $\left(0.25 \times 10^{-2} \mathrm{mr} / \mathrm{h}\right)$

(32) Marukomuryo Coffee garden, $\left(0.15 \times 10^{-2} \mathrm{mr} / \mathrm{h}\right)$

(33) The top of G. Kelut, $1200 \mathrm{~m}$ above sea level, $\left(0.30-3.5 \times 10^{-2} \mathrm{mr} / \mathrm{h}\right)$

(34) The crater lake side of G. Kelut, $\left(0.35 \times 10^{-2} \mathrm{mr} / \mathrm{h}\right)$

(35) Cocoa garden, west to G. Kelut, $550 \mathrm{~m}$ above sea level, $\left(0.27 \times 10^{-2} \mathrm{mr} / \mathrm{h}\right)$

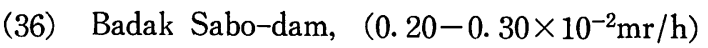

(37) Penataran, $390 \mathrm{~m}$ above sea level, $\left(0.20 \times 10^{-2} \mathrm{mr} / \mathrm{h}\right)$

(38) Salam sand pocket, $220 \mathrm{~m}$ above sea level, $\left(0.20 \times 10^{-2} \mathrm{mr} / \mathrm{h}\right)$

(39) Kalitemas weir, Subersari dam, 200m above sea level, $\left(0.15-0.20 \times 10^{-2} \mathrm{mr} / \mathrm{h}\right)$

(40) Sarangan, $1100 \mathrm{~m}$ above sea level, $\left(0.60-0.80 \times 10^{-2} \mathrm{mr} / \mathrm{h}\right)$

(41) South to G. Law, $1870 \mathrm{~m}$ above sea level, $\left(0.70 \times 10^{-2} \mathrm{mr} / \mathrm{h}\right)$

(42) South to G. Law, $1900 \mathrm{~m}$ above sea level, $\left(0.40-0.50 \times 10^{-2} \mathrm{mr} / \mathrm{h}\right)$

(43) Tawangmang, $1300 \mathrm{~m}$ above sea level, $\left(0.40-0.55 \times 10^{-2} \mathrm{mr} / \mathrm{h}\right)$

(44) Yogyakarta, $\left(1.0 \times 10^{-2} \mathrm{mr} / \mathrm{h}\right)$

(45) Yogyakarta, $\left(0.50-0.70 \times 10^{-2} \mathrm{mr} / \mathrm{h}\right)$

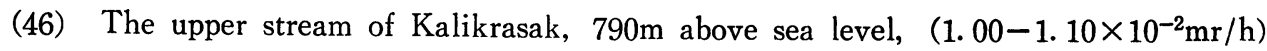

(47) The upper stream of Kalikrasak, $\left(0.90-1.20 \times 10^{-2} \mathrm{mr} / \mathrm{h}\right)$

(48) Kalibugun sand pocket, $\left(0.75-0.90 \times 10^{-2} \mathrm{mr} / \mathrm{h}\right)$

(49) The down stream of Kalikrasak, Juroppo raised bed river, $\left(0.90 \times 10^{-2} \mathrm{mr} / \mathrm{h}\right)$

(50) The down stream of Kalikrasak sand pocket, $200 \mathrm{~m}$ above sea level, $\left(0.90-1.00 \times 10^{-2} \mathrm{mr}\right.$ /h)

(51) The upper stream of K. Putih dam, $860 \mathrm{~m}$ above sea level, $\left(0.90-1.10 \times 10^{-2} \mathrm{mr} / \mathrm{h}\right)$

(52) K. Blongkeng, $\left(0.80 \times 10^{-2} \mathrm{mr} / \mathrm{h}\right)$

(53) K. Krasak, $\left(0.70-0.80 \times 10^{-2} \mathrm{mr} / \mathrm{h}\right)$

(54) Kaliputih dam, $\left(0.90-1.10 \times 10^{-2} \mathrm{mr} / \mathrm{h}\right)$

(55) Kaliboro, $1120 \mathrm{~m}$ above sea level, $\left(0.80-0.90 \times 10^{-2} \mathrm{mr} / \mathrm{h}\right)$

(56) Chikamori point, $900 \mathrm{~m}$ above sea level, $\left(0.80-0.90 \times 10^{-2} \mathrm{mr} / \mathrm{h}\right)$

(57) Borokidur sand pocket, $420 \mathrm{~m}$ above sea level, $\left(0.70-0.90 \times 10^{-2} \mathrm{mr} / \mathrm{h}\right)$

(58) Sukolini dam, $340 \mathrm{~m}$ above sea level, $\left(0.70-0.85 \times 10^{-2} \mathrm{mr} / \mathrm{h}\right)$

(59) Kalisinpin dam, $210 \mathrm{~m}$ above sea level, $\left(0.80-0.93 \times 10^{-2} \mathrm{mr} / \mathrm{h}\right)$

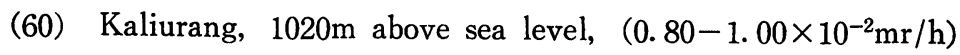

(61) Kaliurang damsite, $850 \mathrm{~m}$ above sea level, $\left(0.80 \times 10^{-2} \mathrm{mr} / \mathrm{h}\right)$

(62) Sangiran agricultural channel, $\left(0.30-0.75 \times 10^{-2} \mathrm{mr} / \mathrm{h}\right.$, average $0.52 \times 10^{-2} \mathrm{mr} / \mathrm{h}$ ) (cf. Fig. 
13)

According to the distribution map of landslides published by Engineering geology section of Indonesian geological survey, many landslides occur centering around Bandung in the western part of Jawa. (Cf. Fig. 1)

Fig. 2 and Fig. 3 show that the measured values of natural radioactivity surveys in the landslide areas along the roads in the western part of Jawa. In the figures No. (4)-No. (9), No. (11)-No. (15) are landslide zone in Tertiary on the coast of the Indian ocean, and the measured value of natural radioactivity survey is low, $0.25-0.51 \times 10^{-2} \mathrm{mr} / \mathrm{h}$ (The value of No. 6 is high because of the part of acidic igneous rocks).

On the other hand No. (16), No. (10), No(1)-No. (3), No. (17)-No. (21) are landslide zone in Quaternary volcanic products distributed in and around the center of the western part of Jawa, and the measured value of natural radioactivity survey is high, $0.50-0.95 \times 10^{-2} \mathrm{mr} / \mathrm{h}$ (The value of No. 19 is high because of the place of hot springs).

From the viewpoint of the intensity of natural radioactivity survey, the measured value is extremely low, $0.15-0.25 \times 10^{-2} \mathrm{mr} / \mathrm{h}$ in and around the volcanic Kelut in the eastern part of Jawa, compared with the other zones. (Cf. Fig. 4-Fig. 5)

This measured value is similar to that in Mikabu greenrocks zone in Japan.

It is the same in Japan that a large change of the measured value relatively appears in the active part of landslide areas, compared with the other zones. However, in the Sangiran landslide north to Surakarta the measured value of natural radioactivity survey is low, which may be because of being rich in clay, and the value on the boundary between displacements is relatively high, as shown in Fig. 13.

\section{References}

(1) SAMPURNO : GEOLOGI GERAKAN TANAH JAWA BARAT. 1975.

(2) SALMAN PADMANAGARA : Gravity and geological studies in JAWA, INDONESIA. 1978.

(3) TOCHIKI S. : Investigation and analysis of landslides in the freacture zone with special reference to Kochi prefecture in Japan. Bulletin of the International Association of Engineering Geology, No. 16. 1977.

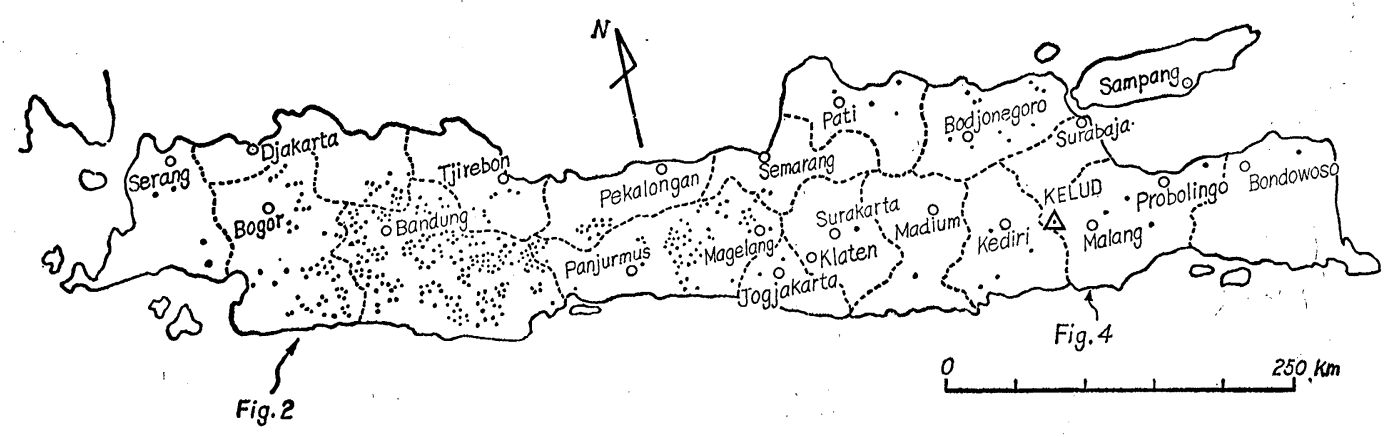

Fig. 1 Distribution of landslides in Jawa. 

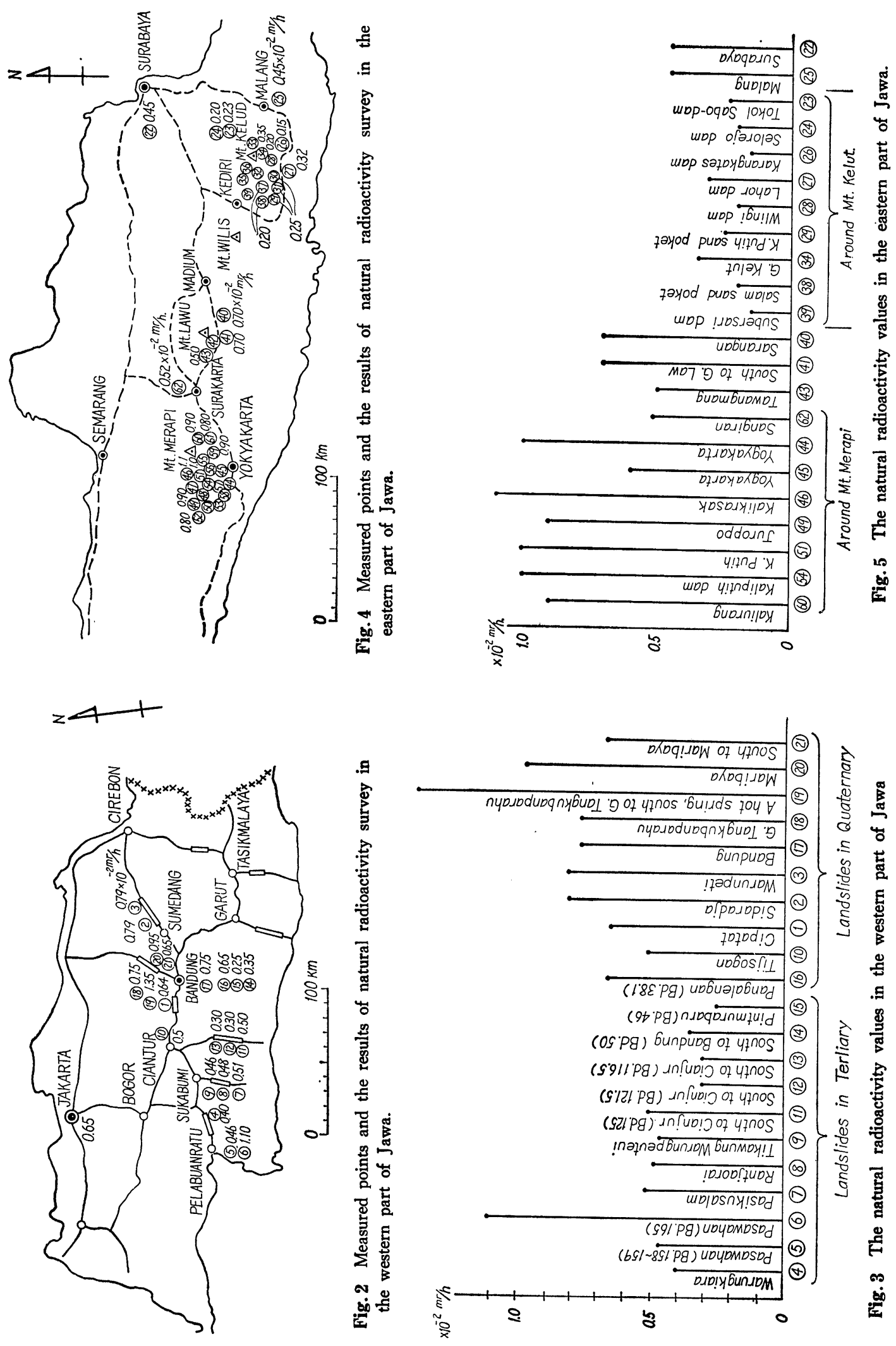
The Natural Radiocativity Survey of Landslides in Jawa Island.
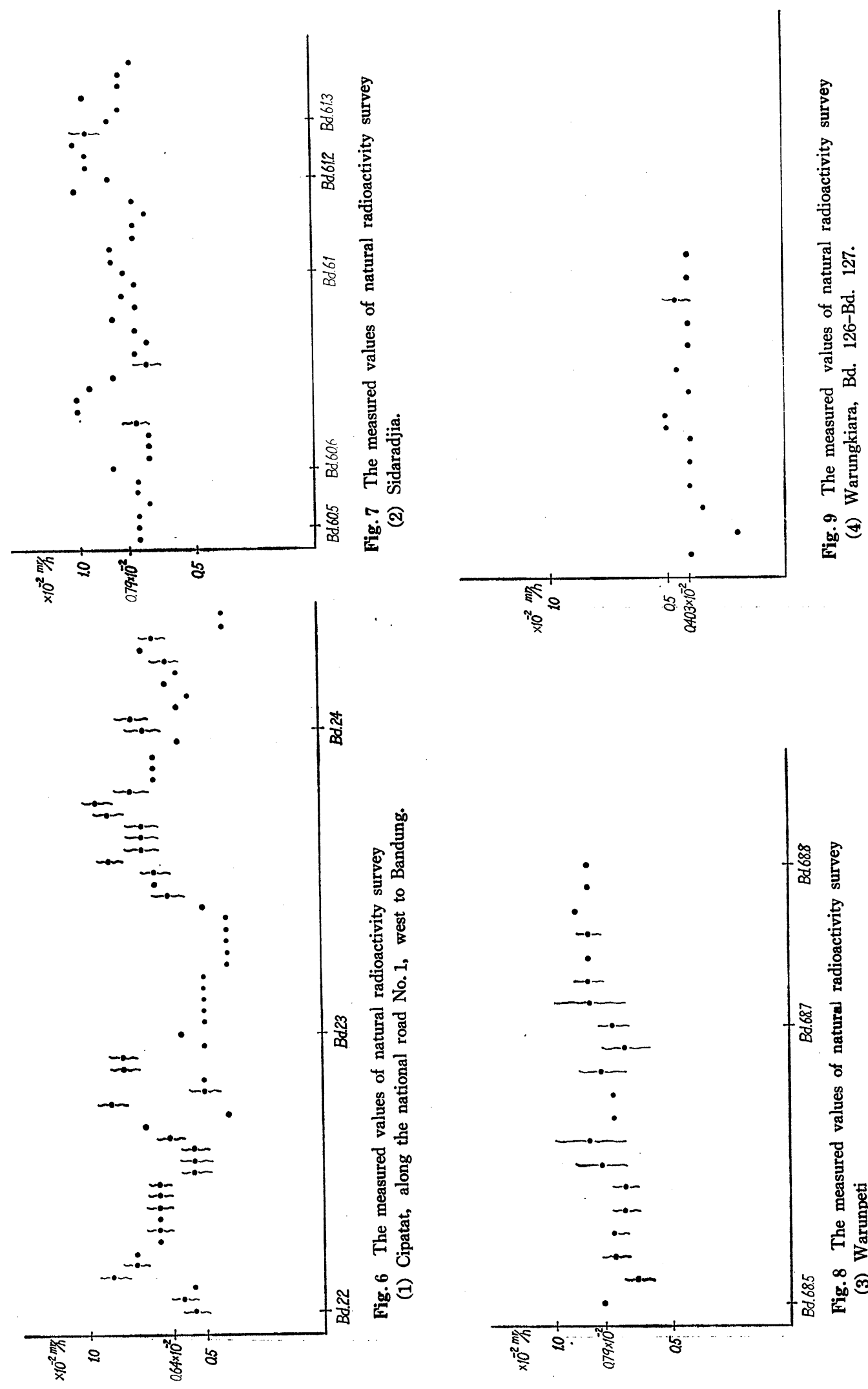
地すべり Vol.17. No.1 (1980)
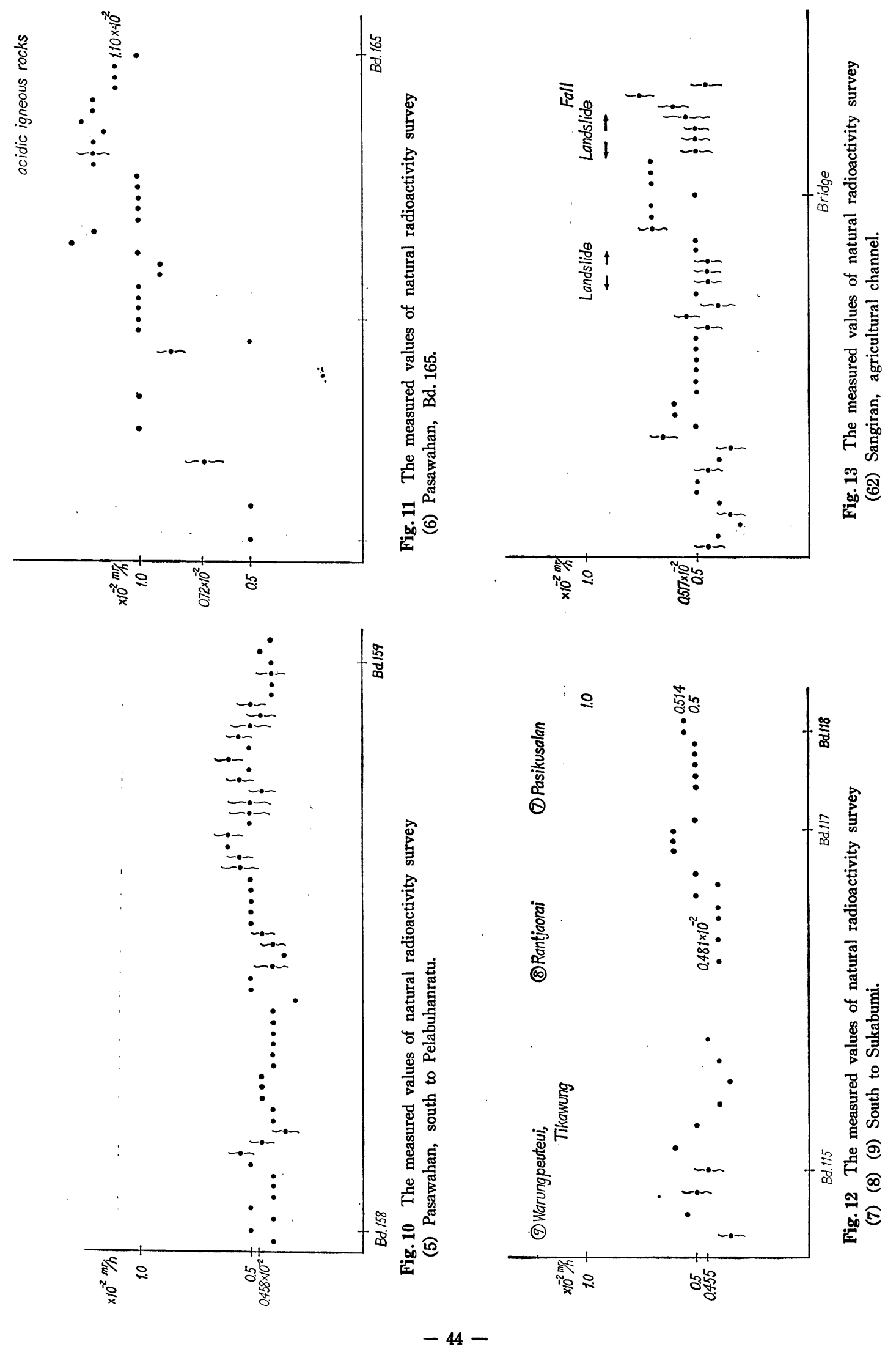